\title{
Desconcerto, função analítica e contemporaneidade ${ }^{1}$
}

\author{
Daniel Delouya ${ }^{2}$
}

O desconcerto não é apenas um momento privilegiado do trabalho analítico, mas parece ser, também, segundo os dois conferencistas, um estado necessário para que uma análise ocorra. Há quem encontre já no inicio do texto do Marcio, onde ele resgata a origem da palavra em seu contrário (concerto), o vestígio de uma outra noção estética freudiana, unheimliche, o estranho ou a inquietante estranheza. Mariano também inicia seu belo texto com o lugar do estranho e do estrangeiro, entretanto, nem ele e tampouco Marcio se referem a tão propalada força do texto de 1919. Talvez porque nosso simpósio enfoca o desconcerto no analista e sua veiculação com algo que diz respeito ao contemporâneo e seu efeito na clinica atual. De fato, estes dois aspectos não se encontram no referido texto de 1919. Me parece que a restauração do lugar do desconcerto na clínica está no cerne da preocupação desses dois autores. Mariano eleva todo o exercício do analista neste resgate, sem o qual o paciente risca perder de vista as trilhas da regra fundamental que rege a análise e a vida psíquica. Para os dois autores é o contemporâneo ou o estado atual da cultura que expõem o espaço analítico às urgências ou às configurações clinicas mais notáveis para essa demanda de restauração do desconcerto, exigindo uma interrogação mais aguda sobre nossa função analítica. Curiosamente, ambos os autores, mesmo se seguindo orientações teóricas ligeiramente diferentes, destacam a angustia ou a neurose de angustia (pânico) com seus estados de confusão e turbulência como característicos dos alertas clínicos do mundo contemporâneo e que nos convocam ao trabalho de restauro do sitio de desconcerto no espaço analítico e no paciente. Para tanto, Marcio se volta, através de Freud e Agamben, aos veios culturais e contemporâneas de nosso mal-estar, enquanto Mariano se detém nas modalidades da escuta das diferentes urgências clinicas e na técnica da restauração do desconcerto. Vou retratar brevemente a contribuição de cada um deles.

\footnotetext{
${ }^{1}$ Este trabalho foi apresentado em oficina sobre as plenárias, eixo "O analista desconcertado: mal estar e cínica" no I Simpósio Bienal "O mesmo, o outro: Psicanálise em movimento" da Sociedade Brasileira de Psicanálise de São Paulo.

${ }^{2}$ Psicanalista da SBPSP com funções didáticas
} 
Marcio remonta o contemporâneo à insistência do ato inaugural do humano no mito freudiano: o assassinato do pai. Esse eu originário, o grupal (dos irmãos) almejava por algo inesperado e de dolorosa aquisição: $a$ individualidade. Aquisição que Freud atribui em 1921 (A psicologia das massas e analise do eu) ao surgimento do poeta: o líder do assassinato, o filho caçula, querido das mães pela potência libidinal que representa em poder demolir o regime autoritário e perverso do pai da horda. Esse herói épico que traz a palavra - a linguagem - para os homens para que abdiquem da força toda poderosa da ilusória luz ofuscante do grande pai da história atávica e admitam, atravessando o pânico e a angustia, a escuridão da solidão, o luto. O que permite constituir um espaço próprio, circunscrito, do individuo no mundo do desconhecimento, em que a ruptura e a cesura podem ter vez para o desconcerto do sujeito e a manutenção do fogo da vida. Marcio exemplifica esse roteiro através de uma vinheta clínica de um homem em que a estagnação melancólica do ambiente materno originário encontra alivio na fuga proporcionada pelo trafego do mundo contemporâneo: a aceleração toda dominante do capital na rotina de um executivo que encontra falsa morada nos hotéis em que repousa em meio aos negócios que trava entre distantes regiões geográficas pelo mundo. Apenas o medo de adentrar os elevadores flagra o terror de encontrar um loco, um sitio próprio. A analise vai permitir a irrupção do pânico em sua ilusória morada e a busca autentica de uma, individual, que lhe é mais própria.

Retomando os desafios clínicos, Mariano se serve da conhecida associação do trabalho do analista com o dos detetives segundo os diferentes gêneros literários. Ele distingue entre os desafios em que o enigma, o mistério e o segredo se colocam, diferentemente, em pauta na análise. No trabalho clássico em que o enigma do sintoma se coloca no primeiro plano, a escuta permite a dissolução deste desconcerto neurótico. Já no caso do mistério, a fuga desses pacientes para o gozo, defrontam o analista com as configurações limites nos diferentes modos de atuação. $O$ analista detetive deve aqui lançar mão de estratégias menos arqueológicos e mais de investigação forense para maior aproximação com a loucura ou o mundo de 'crime' em questão. Ainda assim, nesses dois modos, a escuta promove a fala e permite o desconcertado analista a avançar com o paciente. Já o terceiro modo, do segredo, age em oposição à regra fundamental, revelando um modo perverso de agir em que a investigação incorre num campo de espionagem, onde a intrusão e a manipulação reinam. Nesse terreno, o exercício do analista consiste em reverter a perspectiva e restaurar, pelo meio de trabalho da 
construção, um regime de brincar possibilitando o advento do desconcerto no paciente. $\mathrm{O}$ analista se empenha como detetive selvagem ao modo performativo utilizando-se de seu desconcerto para implanta-lo no paciente. A organização paranoica, de espionagem e de vigília se reporta ao estado de desamparo de origem em que um meio carente simbolicamente despertou a sobrevivência erguendo um universo destrutivo em que o desejo e a lei foram banidos e devem retornar.

Por que nos preocupamos com o desconcerto e insistimos sobre ele na clínica e na cultura? Por que existe a tendência de escamoteá-lo da mesma forma com que o $E u$ tende a recalcar tudo que é disruptivo com sua aparente coerência. Algo insiste em voltar, unheimliche, como estranho e desconcertante. Essa volta inquietante não é somente de um recalcado, mas também das próprias instancias, que recalcam e querem tudo domar e dominar, em suas formações inicias. Freud em seu texto de 1919 demonstra como o duplo, esse outro de outrora do Eu, padrinho de sua apólice de vida e, paradoxalmente, de ameaça de sua morte, é aquele que sua volta se coloca à espreita, gerando confusão, e tornando tributário de todas armações defensivas, paranoicas e manipuladoras, que convocaria a cena a ação do detetive selvagem anunciado pelo Mariano. A coerência e a organização são uma consequência do afã de dominação, de negação e recusa desse desacordo (Agamben) fundamental que sujeito e a cultura abrigam em si. A mania de dominar, essa busca pela luz, pelo brilho, pelo fetiche, erguendo monumentos sobre os cantos escuros que habitam os buracos, fraturas e cesuras que nos constituem é o motor das promessas que visam superar, na vida e na cultura, o nosso desamparo e a realidade de castração que construímos penosamente.

Basta mencionar o que se pode imaginar com a dita quarta revolução da infosfera, citada pelo Marcio, onde se encontra o sujeito-conectado-móvel com 4 biliões de internautas. Rede pela qual poderia o internauta ter no futuro próximo as precisas informações sobre seu sistema genético e metabólico, perfeitamente mapeado, com todos os diagnósticos sobre os perigos que pode correr e as instruções das medidas diárias que deve tomar para sana-las. Dominação, garantias, poder ilimitado sobre a saúde ... apenas uma das maravilhas entre muitos que a ciência nos reserva... qual seria seus alcances sobre as ilusões em sanar nossos mal-estares em cultura e trazer 'felicidade'??? 
O desconcerto, em suas variadas formas, evidencia essa exigência de deflagrar as rupturas, e propiciar as ligações das pontes construídas sobre os abismos do desamparo para consolidar o discurso vivo da linguagem e suas perplexidades (Mariano). As contribuições de Marcio e Mariano dão um sopro para preservar o fogo da psicanálise. 